\title{
MOBILE EDUCATION OPPORTUNITIES FOR NON-PHILOLOGY STUDENTS IN LEARNING A FOREIGN LANGUAGE
}

Summary. The article deals with mobile means for learning English on the whole and innovative opportunities of the Internet and Apps in particular. The author analyzes the peculiarities of teaching and learning English and comes to the conclusion that the easiest way to develop different competences and improve communicative skills and to extend vocabulary of English is to use modern technologies like mobile and internet apps, chat in different Internet forums and sites for learning languages, learn English trough Internet resources like watching developing video and audio materials online. Also the author notices that such approach is good for distant learning or self-education.

Keywords: m-learning, e-learning, mobile apps, distant education, digital platforms, self-education, selfeducation competence.

Буровицька A.I.

Чорноморський національний університет імені Петра Могили

\section{ОСВІТНІ МОЖЛИВОСТІ МОБІЛЬНОЇ ОСВІТИ СТУДЕНТІВ-НЕФІЛОЛОГІВ ПРИ ВИВЧЕННІ ІНОЗЕМНОЇ МОВИ}

Анотація. Попередні дослідження включали терміни електронного навчання та m-learning, їx категорії, функції для навчального процесу в цілому, однак мало досліджень були присвячені можливості мобільного навчання для студентів-нефілологів у вивченні іноземної мови. База мобільних додатків і технологій постійно зростае, що змусило нас розглянути найбільш використовувані і корисні в наш час додатки та їх користь для навчального процесу студентів різних спеціальностей. Мета даного дослідження полягає в описі сучасних можливостей найбільш використовуваних мобільних засобів та Інтернет-ресурсів для дистанщійного навчання англійської мови з викладачем або самостійно для студентів нефрілологічного профілю, щоб показати їхній потенціал самоосвіти. в цілому та інноваційні можливості Інтернету та програм, зокрема. Автор аналізує особливості викладання та вивчення англійської мови і приходить до висновку, що найпростіший спосіб розробити самоосвітню компетенцію та вдосконалити комунікативні навички, розширити словниковий запас англійської мови - це використання сучасних технологій, таких як мобільні та інтернет-програми, чати на різних інтернет-форумах та сайти для вивчення мов, вивчення англійської мови через інтернет-ресурси онлайн. У статті викладені сучасні можливості мобільних засобів та деяких інтернет-ресурсів для вивчення англійської мови дистанщійно, такі як гнучкість і адаптивність, побудова модулів, нова роль вчителя-координатора, дистанційні форми контролю. У роботі висвітлено значення засобів Інтернет та мобільних технологій, описано мобільну освіту та її компоненти, що включають в себе використання мобільних додатків та спілкування з носіями мови дистанційно, уроки через чати та Skype, використання навчальних блогів, електронні курси та спілкування через мережі та месенджери, а також у процесі розробки комп'ютерної гри. Зазначається, що розвиток мобільних технологій допомагає нам отримати доступ до Інтернету і величезної кількості додатків мобільно. Запропоновано нові ідеї для подальшого розгляду, як дослідження, що спрямовані на пошук нових стратегій розвитку компетентності у письмі, читанні, аудіюванні та говорінні для студентів нефілологічних спеціальностей. Описано майбутні перспективи подальшого дослідження.

Ключові слова: мобільна освіта, електронна освіта, мобільні додатки, дистанційна освіта, самоосвітня компетенція.

Tntroduction. The importance of studying Lthe problem of organizing educational process through the resources of the Internet and technologies is determined by the objectives of modernization of education in the institution as well as self-education. The new vector of education development involves using different Internet resources and technologies what can help to easy and improve education process, can help in the context of fast learning updating, in communicating in different specific spheres. World standarts of education in the 21st centuries have been changed a lot and set new requirements for teaching and learning foreign language.

The problem of technologies implementation into educational process and using apps was described in the works of the foreign and Ukrainian scientists R. Gryshkova, M. Hromiak, M. Kademia, N. Kijanovska, S. Semerikov, S. Butyrina, practice of a distant education and mobile technology was discussed by A. Andreyev, Y. Vahramenko, V. Kuharenko, G. Kashina, S. Kravets, Y. Vasylenko. Mobile education on the world scientific area was researched by Mehdipour Y., Zerehkafi K., Hea-Suk K., Guo H., Kigen D., Evans T., Beits T. and others.

The earliest investigations included e-learning and m-learning terms, their categories, functions for educational process in general however few investigations were devoted to show mobile education opportunities for non philology students in learning a foreign language. The base of mobile apps and technology is constantly growing what forced us to discuss the most used and useful nowadays and their benefit for educational process.

The purpose of this research is to describe modern opportunities of the most used mobile means and Internet resources for learning English remotely with a teacher or yourself for non-philology students, to show their self-education potential. 
Research body. Mobile education is one of the form e-learning what comprises new informational communication technologies and using multimedia and mobile technologies, Internet network with the aim of improving quality of education and remote education and collaboration between students and teachers [1].

According V. Kuharenko such mobile education has the following main features:

- Flexibility and adaptability;

- Module building;

- New role of a teacher-coordinator;

- Distance forms of control;

- Using special means of education [7, p. 12].

Kravets notices that forms of mobile distant educations should have different models of professional studying organization from autonomy to the common cooperation between the subject of pedagogical process in the area of e-platforms [6, p. 21].

The main peculiarities of the new approach is complexity, system structure, developing new up to date pedagogical technologies on the base of informational environment (problem and project education, education in cooperation) [4].

As a result, higher education is entering a new and stimulating period and teachers are becoming facilitators to develop and apply students' competencies. That's why it is indispensable to look for the new means of collaboration.

Chuenko L. admits that nowadays some spheres of life are developing so rapidly and dynamically that it difficult to keep up with the demands they are offering to a would-be specialists. So, new competencies, like self-study and autonomy, as well as certain flexibility, need to be developed. Such competence can be gained and developed in the process of mobile education [9, p. 93].

During the process of such education different methods can be used. By the way the method of teacher-student cooperation has been already changed. It provides more autonomy for the students $[5$, p. 6].

Such new process of language learning in itself requires authentic communication and constant practicing, the activities that can be realized through interaction with people, language materials and learning environments, including technological professionally oriented terms but also today we definitely can't imagine learning and teaching a foreign language without using new technologies, means and methods. Nowadays students have absolutely different needs and this approach involves combining the process of learning a foreign language with development of personal qualities of students and obtaining professionally-oriented competence and knowledge of the given language.

The aim of such training involves professional-oriented communicative competence that will allow them to use a foreign language during their professional activity. One of the most important competences what students can gain in the process of educational activities during a professionally oriented training is self-study competence. Also we can outline a competence to collect and sort materials from different resources. According to the survey which was held in National Black Sea State university more then $70 \%$ of teachers use different means of the Internet resources and sites to make class work more effective and intensifying.
Distance education comprises all possible means what can be used or implemented remotely, Between a lot of resources what can be used for teaching and learning English and communication with the students inside and outside the class we can outline the next means:

- Mobile learning and using mobile applications, BYOD;

- Digital platforms;

- Skype education;

- Electronic systems like Moodle;

- Online corpora;

- Using e-mails;

- Education through the social networks;

- Web bases Internet resources and messengers;

- Electronic courses;

- Personal blogs.

Lets discuss some mobile education means, their use and opportunities for non-philological department students.

\section{Mobile applications and BYOD.}

About $95 \%$ of the students who took part at the survey in Black Sea National University admitted that they use mobile devices for educational purposes every day. And if teachers and students are gaining so much from their mobile devices, why ban them from classrooms? Now we can use the devices to make educational process more available for everyone such as a lot of students and teachers can't afford to buy expensive paper materials.

In summary, mobile apps have encouraged exciting opportunities for personalized and learner-centred environments with flexible access to learning materials anytime and anywhere. The novel and enjoyable ways of learning would have a great potential to increase learning motivation and encourage lifelong learning habits [2, p. 21].

K. Hea-Huk admits that researchers found that mobile technologies support language learning in different areas such as vocabulary learning (, pronunciation practice, listening skills, English reading with personalized intelligent, and several theme-based m-learning activities improving contextual language learning experiences [3].

The development of mobile technology helps us to access the internet and a huge variety of apps on the go. Easy Ten, Learning English with the New Your Times, English At Work will be useful for learning new words and phrases, Grammarly, Babels - for checking grammar and correction your own mistakes.

Use of m-learning technology means in the educational process shows that means of m-learning improves students' skills in learning, growth level of knowledge, increases the competitiveness of graduates in the labor market and flexibility for students studying at a distance. Giving learners the advantage of communicating in real-time conversations with English speakers, probably the most exciting (and futuristic) technological advancement has come in the form of Skype and FaceTime. Tools such as video-conferencing also offer teachers the opportunity to link to other classes around the world, also gaining support from other teachers and students. There are many new apps on the market for speaking with other learners, such as CoffeeStrap and HelloTalk meaning you can converse with native speakers right from your phone. Skype is a great way for students to practice their speaking and listening skills with 
other people from any location. Students can have question-and-answer sessions with authors of books, attend video-conferences and virtual field trips, interview professionals, and connect with students from other cultures and countries. Additionally using multimedia is recommended because it is effective method of repeating, systematization and generalization of student's knowledge. The ability to communicate online with people outside the classroom via Skype gave great opportunities for distant education . Communication through the messengers, forums, sites could give much-needed motivation to students who otherwise might not have the opportunity to interact with anyone in English. The messengers like Viber, WhatsApp, Telegram can also help to build channels of communication beyond the classroom. The participants like using mobile apps for learning English because 60 these learning apps fitted their personal needs well. They could choose topics that suit their personal interests or needs from a variety of situated conversations that the apps provided [2, p. 60].

2. Communicating with people online. It is known that encouraging communication outside the class is really important for developing student's writing and speaking skills but nowadays students are very mobile so it is easier for them to communicate online on different websites, reading blogs or playing a new computer game.

3. Digital platforms. When we discuss innovation, we often immediately think of the internet and what we can now do online. Different communication sites have become a platform for learning. The most widespread digital platforms what we use now are Edmodo, Facebook.Cloud-based tools like Google Docs have also become indispensable.

4. Using online authentic materials. One of the biggest benefits of the internet for language learners is the sudden widespread availability of authentic resources. It opens the access to the daily news, watching trending videos on YouTube, TED, read online newspapers, etc.It can help to develop a pedagogically sound approach to language learning, showing how we can combine language learning with digital video to create effective lessons. Thus, the described method of learning English is used to facilitate educational process, communication, memorizing vocabulary and avoiding errors in their use. It is crucial for students of IT, future lawyers, psychologists,ecologists to be aware of peculiarities of professionally oriented lexical vocabulary of their sphere. So they can use such programmes and applications what will be able to give them such opportunity. Definitely useful for this purpose are such programmes as English at work, Learning English with the New York Times because they include audio and video materials, case methods what can happen at work, a list of the useful phrases for the topic and the exercises to practice grammar and writing skills.

5. Online corpora. The use of corpora - large text collections used for studying language structures, frequencies. Now it has become available online, and quite a few for free, teachers now have access to information about the way language is used in authentic texts and speech. Teachers no longer have to panic when students ask them about the difference between similar terms like 'trouble' and 'misfortune', 'problem' and 'concern'.

Conclusion and ideas for the further investigation. To conclude we want to highlight the great value of the Internet means and mobile technologies we have approached here, such as mobile education what includes using mobile applications and communicating with native speakers remotely, lessons through the chats and Skype, using educational blogs, corpora, electronic courses and communication through the networks and messengers as well as in the process of playing a developing computer game. Mobile education can greatly improve students' confidence in using English in different spheres and it is not exhausted for them. Also, using mobile education can decrease in training costs and extend our opportunities in learning and teaching. It was noticed that we have just partly implemented mobile learning such as there are some obstacles on the way of its full implementation. And the evaluation of using mobile apps for English learning from language learners' perspective is still at the early stage. Having said this it is important to find a way to practice what you learn. Talking face to face with a native speaker through the chat or via Skype is a great method if you have the opportunity, but what is necessary is not to forget that the internet provides us with many more opportunities to communicate without leaving home.

The number of educational opportunities can be enlarged with the help of digital gadgets and the Internet. Thus, further research should be directed on finding new strategies of developing competence in writing, reading, listening and speaking for students of non-philological departments.

\section{References:}

1. E-learning / E-Soft Development (2011). URL: http://www.web-learn.ru

2. GuoH.Analysing and Evaluating Current MobileApplications for Learning English Speaking. URL: https://englishagenda. britishcouncil.org/sites/default/files/filefield_paths/analysing_and_evaluating_current_mobile_applications_v2.pdf

3. Hea-Suk K. Emerging mobile apps to improve English listening skills. Multimedia-Assisted Language Learning. URL: http://journal.kamall.or.kr/wpcontent/uploads/2013/09/16-2-HSKim.pdf

4. Hromiak M. Problemy vprovadgennia ta vykorystannia elektronnogo navchannia u vyshchyh navchalnyh zakladah. URL: http://dspace.tnpu.edu.ua/handle/123456789/93

5. Kashina G. Teoretyko-metodologichni osnovy vykorystannia dystancijnyh form navchannia u systemi pisliadyplomnoi pedahohiichnoi osvity. URL: http://journals.uran.ua/sr_edu/article/view/107538/103044

6. Kravets S.H. Functions of distance learning in the system of training of future skilled workers. URL: http://lib.iitta.gov.ua/705481/1/kravets\%20S.G_tezy

7. Kuharenko V.M., Syrotynko N.H., Rybalko O.V., Bohachkov Y.M. (2008). Technologiya rozrobky dystanciynogo kursu : navchalnyi posibnyk / Bykov Y.V. Kyiv : Milenium, 24 p.

8. Mehdipour Y., Zerehkafi H. (2011). Mobile Learning for Education: Benefits and Challenges. International Journal of Computational Engineering Research, vol. 03, issue 6. URL: http://pakacademicsearch.com/pdf-files/ com/319/93-100\%20Volume\%203,\%20Issue\%206,(Version\%20III)\%20June,\%202013.pdf

9. Chuenko V.L. (2018). Teacher-students interaction as a means of developing Students' ESP competence. Naukovi praci. Mykolaiv, pp. 93-95. 